\title{
The Perceived Leadership Styles of Division Chiefs and Department Heads of the Local Government Unit of Cabanatuan City in the Philippines
}

\author{
Maridel Z. Viernes, Christian P. Binuya, Marichris S. Lanorio, Anthony B. San Pedro \\ Department of Public Administration, Nueva Ecija University of Science and Technology, \\ Cabanatuan City, Philippines \\ Email: maridelzabatviernes28@gmail.com,cpbinuya@yahoo.com,chrisslanorio@yahoo.com, \\ anthonybasasanpedro@yahoo.com
}

How to cite this paper: Viernes, M.Z., Binuya, C.P., Lanorio, M.S. and Pedro, A.B.S. (2018) The Perceived Leadership Styles of Division Chiefs and Department Heads of the Local Government Unit of Cabanatuan City in the Philippines. Open Access Library Journal, 5: e4763.

https://doi.org/10.4236/oalib.1104763

Received: July 8, 2018

Accepted: August 19, 2018

Published: August 22, 2018

Copyright $\odot 2018$ by authors and Open Access Library Inc.

This work is licensed under the Creative Commons Attribution International License (CC BY 4.0).

http://creativecommons.org/licenses/by/4.0/

\section{(c) (i) Open Access}

\begin{abstract}
Leadership styles are as old as human civilization. From the city state of polis to the modern public governance era, leadership style steers up the organization to a higher level of productivity. It breeds cooperation and motivation among employees. Leadership is essential in the organization. While leadership is different from person to person, it is affected by perception. These perceptions influence expectancies and elicit actions from subordinates. The study measures the leadership style of department heads and division chiefs using the following thematic areas: 1) formulation of organizational objectives; 2) identification of programs and projects; 3 ) making decisions; 4) handling complaints and issues; 5) and addressing organizational problems. The study also compared their leadership perceptions and determined whether there is significant difference in styles using the classical models of leadership, namely: 1) democratic; 2) autocratic; and 3) delegative. Majority of the respondents (28) perceived that there is no significant difference between their leadership styles.
\end{abstract}

\section{Subject Areas}

Politics

\section{Keywords}

Leadership style, Democratic, Autocratic, Delegative,

Leadership Perception 


\section{Introduction}

The Local Government Code of 1991 provides for the decentralization of power from the national government to different government units. The decentralization also created an administrative set-up of devolution to make the government nearer to the people, including the services they are providing to the community. These set-ups are believed to increase the organizational effectiveness of LGU and create higher level of organizational performance [1]. However, despite devolution and the promise of development it portrays, many perceived that the government is a failure to contribute to genuine national development. Many local governments in the Philippines still fail to address the most basic needs of their citizens. Some local government leaders lack the actual observance of transparency and accountability which would otherwise create a genuine space for democratic governance in the local level [2].

In a constantly changing political practice, effective leadership is very important. Local government leaders face the challenges in administration such us raising local revenues and solving various health issues. The complexity of society also creates other problems related to rapid growth of urban centers, like preparing for rapid urbanization that would need more infrastructure facilities, and improvement of social services, education, peace and order, and adaptation to climate change. To meet these challenges, a leader must be highly skilled and effective, to be able to steer up the municipality towards progress.

Leadership style plays a vital role in managing human resources. "Leadership is shifting of one's own vision to higher sights, the raising of man's performance to higher standards, the building of man's personality beyond its normal limitations [3]. In the foreword of Jeevan Jyote and Sonia Bhau and in an ordinary office set-up, human resources are the most vital part of an organization. They are the valuable assets, which are unique and can generate innovative ideas for sustainable and competitive advantages" [4]. It is essential to keep them motivated by means of leading and managing them efficiently.

Leadership is the core of an organization. It manages the most essential part of an institution-human resources. "Leadership is a social influence process in which the leader seeks the voluntary participation of subordinates in an effort to reach organizational goal", according to [5]. Leaders impact their subordinates in different manners to become effective and efficient in attaining the objectives.

Transforming leadership is a process, which the leaders and followers help each other to have a higher morale and motivation. Transformational leaders can inspire the followers to change expectations, perceptions and motivate them to achieve common goals through the strength of their vision and personality [6].

Later on, Bernard M. Bass expanded the work of Burns and defined transformational leadership as based on the impact that it has on followers [7]. "Transformational leaders inspire the followers, as well as persuade, provide meaning and understanding in their work", according to [8].

There are three classic styles of leadership that has been developed by Kurt 
Lewin. These are the Autocratic, Democratic (Participative) and Delegative (Laissez-faire) leadership. Authoritarian leaders make policies and decide appropriate division of labor. The power is centralized on one person; it is gained through punishment, threat, demands, orders, rules, and regulations. This is appropriate in settings with a constant stream of new employees, limited decision-making time or resources, and those with a need for large-scale coordination with other groups and organizations, but it is not suited to environments in which members desire to share their opinions and participate in decision-making processes. Thus it may lead to high member dissatisfaction, turn-over, and absenteeism [6].

According to [9] participative leaders distribute of responsibility and empower members, they aid the group's decision-making process. This is participatory leadership that requires collaboration between leaders and members. It is a power-sharing arrangement in which workplace influence is shared among individuals who are otherwise hierarchically unequal [10], 1979, as cited in Howard [1]. But this must be use carefully to prevent lower employee satisfaction and productivity when the inputs of the member are rejected. This can be prevented by developing mature teams. Experienced and cooperative that can support the group's goal even when their own suggestions are not adopted.

Delegative leadership is having a minimal interference in decision making and there is an absence of policies or group related decisions. Members are responsible for all goals, decisions, and problem solving. The leader trusts the member to make appropriate decisions and bring in highly trained and reliable members into the group or organization. This is applicable to highly experienced and motivated members but not suited to members that require feedback, direction, oversight, flexibility, or praise.

A study at the University of Iowa by Kurt Lewin explored the three leadership style: autocratic, democratic and delegative. This study determined the effect on satisfaction and frustration-aggression level by different leadership styles on the same groups. It reveals that democratic leadership generally has a higher level of satisfaction and is less aggressive.

The Department Head of Cabanatuan City Local Government Unit may play a combination or single type leadership in their organizations. These may be affected by age, gender, educational attainment and length in service on deciding the appropriate leadership style. The perception of Department Head may greatly effect on leadership behavior. These perceptions set up expectancies that may affect the leader's own sense of latitude to take or not take actions affecting followers [11]. The follower perceptions are a significant way in determining the leader behavior that may serve as constraint or check.

David Siegel [12] has concluded that "leadership of a Chief Administrative Officer, have a great impact to the employees as well as to the image of the mayor and his council. A Chief Administrative Officer can make a mayor or council look good or bad. They can also be a source of pride and motivation to the employees of the municipalities. They can be the conduits of information 
between community organizations and municipality".

Many of the leadership study is done in school and hospital setting. Only a few of the researches studied leadership in Local Government Unit, and described the differences of leadership styles of Department Heads and Chiefs as they are perceived by followers and public clientles.

\subsection{Theoretical Framework}

The Path-Goal theory, inspired by the work of Martin G. Evans (1970), can best be thought of as a process by which leaders select specific behaviors that are best suited to their employee's needs and their working environment, so that leaders may best guide their employees through their path in the obtainment of their daily work activities (goals) (Northouse, 2013). The leaders encourage and support their followers in achieving the goals they have set by making the path that they should take clear and easy.

Path-Goal theory can be applied and work with any of the classic style of leadership simultaneously. In Path-Goal theory, the leader's role is to assist employees in attaining goals and to provide the direction and support needed to ensure that their individual goals are in concert or compatible with the organization's goals. Classical type of leadership may use less authority and leaders act as guide, mentor, and coach to enhance the vision of the followers. This theory and leadership style both guide and direct the employees that may increase the job performance for the achievement of organizational goal.

\subsection{Statement of the Problem}

This study described the leadership styles of Division Heads and Chiefs of the Local Government Unit (LGU) of Cabanatuan City.

Specifically, the study sought to answer the following:

1) How do the LGU Department Heads perceived their leadership styles on

a) Formulating organizational objectives;

b) Identifying programs and projects;

c) Making decisions;

d) Handling complaints and issues; and

e) Addressing organizational problems?

2) How do the LGU Division Chiefs perceived their leadership styles on the foregoing domains?

3) How do the perceived leadership styles of Department Heads and the Division Chiefs compare?

The study utilized the Department Heads and Division Chiefs within the Cabanatuan City Local Government Unit as respondents. This study is limited on leadership style which is authoritarian, democratic, and delegative. That focuses on formulating organizational objectives identifying programs and projects; making decisions; handling complaints and issues; and addressing organizational problems due to the limited time of the researcher to conduct this study. 


\section{Methodology}

\subsection{Research Design}

The study employed the descriptive method of research. A descriptive design is used to obtain information of a condition that presently exists. The study described the leadership styles of Division Heads and Chiefs of the LGU of Cabanatuan City as they are perceived by them.

\subsection{The Research Locale and Participants}

This study was conducted at the Local Government Unit of Cabanatuan City. Cabanatuan City is the center of business and trade in Nueva Ecija. The respondents of the study were 10 Department Heads and 28 Division Chiefs of the Cabanatuan City Local Government Unit which were chosen from a population of 76. The samples were identified using simple random sampling.

\subsection{The Research Instruments}

A predesigned questionnaire was used as a tool to gather data. It contained items on three different leadership styles in so far as formulating organizational objectives, identifying programs and projects, making decisions, handling complaints and issues, and addressing organizational problems are concerned.

The items in the questionnaire were answered using a five-point Likert scale. The scale measures the degree of agreement or disagreement of the respondents to their leadership practices as they perceived them. The scale is described as follows: 5-Strongly Agree, 4-Agree, 3-Moderately Agree, 2-Disagree, and $1-$ Strongly Disagree. The items were categorized into the three different leadership styles namely: democratic, authoritarian, and delegative.

\subsection{Statistical Analysis of Data}

1) The perceived leadership styles of the Division Heads and Chiefs were based on their degree of agreements to items describing the leadership style namely: a) formulating organizational objectives, b) identifying programs and projects, c) making decisions, d) handling complaints and issues, and e) addressing organizational problems. Their degree of agreement/disagreement described their leadership style namely: a) democratic, b) authoritarian, and c) delegative. The degree of agreement/disagreement was scaled as follows:

\begin{tabular}{llc}
\hline $4.21-$ & 5.00 & Strongly Agree \\
$3.41-$ & 4.20 & Agree \\
$2.61-$ & 3.40 & Moderately Agree \\
$1.81-$ & 2.60 & Disagree \\
$1.00-$ & 1.80 & Strongly Disagree \\
\hline
\end{tabular}

2) To determine significant differences on the leadership styles of the division heads and division chiefs, $t$-test for independent samples was used. The two tailed test at 0.05 level was used to test the hypothesis. 
The paradigm in box 1 indicates the input to be used in the study such as described the perceived leadership styles of Division Heads and Chiefs of the Local Government Unit (LGU) of Cabanatuan City based on five (5) factors. These are the following: a) formulation of organizational objectives, b) identification of programs and projects, c) in making decisions, d) handling complaints and issues and e) in addressing organizational problems. Thru the process of using the questionnaire, the Department Heads and Chiefs will identified their perceived leadership style with three (3) classical types that are: a) democratic, b) authoritarian and c) delegative. Then, translate it in output by comparing the differences on perceived leadership style of Department Heads and Division Chiefs. Through this process it may determine the strength and weaknesses of the leadership thru feedback mechanism. The strength area will be continued in practice and further develop, while the weakness area will be improve. The input-output-process continues (Figure 1).

\section{Results and Discussion}

The present study was an attempt to describe the current leadership style of Division Heads and Chiefs in Local Government Unit (LGU) Cabanatuan City, as perceived them. Measured the differences in their leadership perception was also determined. The results obtained were put through statistical analysis and are presented in this present chapter. For the better understanding the results were divided and presented under following:

\subsection{Describe the Perceived Leadership Style of the LGU Department Heads on the Following}

\subsubsection{Formulating Organizational Objectives}

Table 1 provides for the leadership styles of the participants based on the classical leadership models. As the table shows majority of the department heads believe that they exercise democratic leadership as signified by 4.20 mean score or

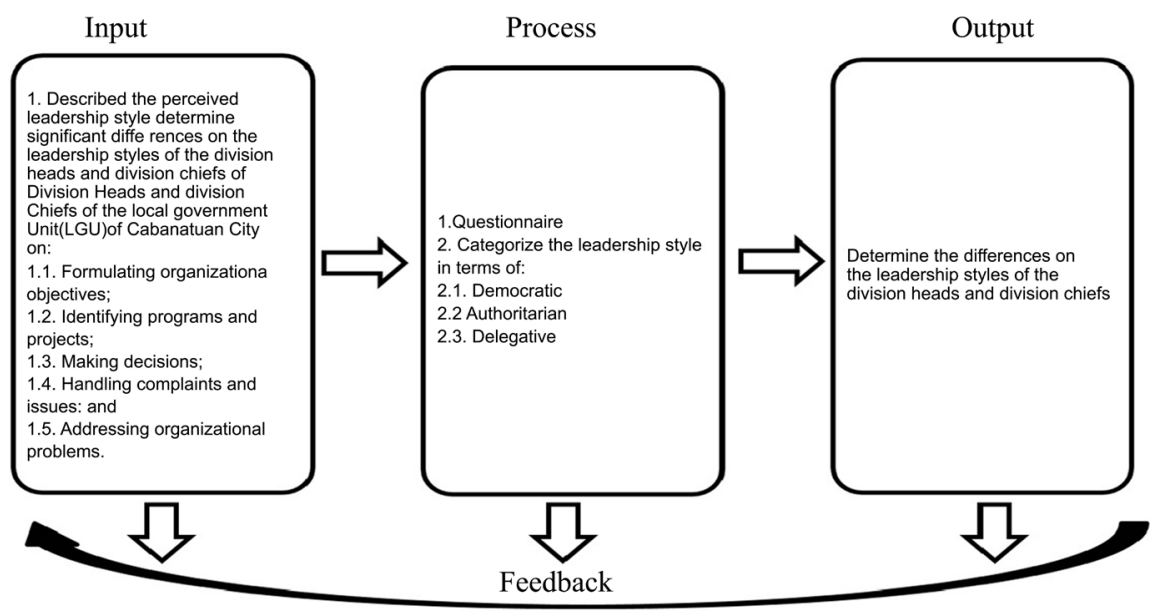

Figure 1. Research Paradigm. 
Table 1. Department Heads in formulating organizational objectives.

\begin{tabular}{lllll}
\hline \multicolumn{4}{c}{ Department Heads } & \multicolumn{3}{c}{} \\
\hline Leadership style & \multicolumn{1}{c}{ 1) Formulating organizational objectives } & & \\
\hline DEMOCRATIC & $\begin{array}{l}\text { To formulate the organizational objectives the employees } \\
\text { exercise self-direction encourage by the Department Head. }\end{array}$ & 4.20 & $\begin{array}{c}\text { Strongly } \\
\text { Agree }\end{array}$ \\
AUTOCRATIC & $\begin{array}{l}\text { To formulate the organizational objectives the Department } \\
\text { Head direct and threatened with punishment the } \\
\text { employees. }\end{array}$ & $\begin{array}{l}1.80 \\
\text { The organizational objectives are formulated by the } \\
\text { employees in their own ways. }\end{array}$ & 2.50 & Disagree \\
\hline
\end{tabular}

Legend: 1.00 to 1.79 Strongly Disagree; 1.80 to 2.59 Disagree; 2.60 to 3.39 Moderately Agree; 3.40 to 4.19 Agree; 4.20 to 5.00 Strongly Agree.

strongly agree. Other responses as to the leadership styles are presented below, to wit.

Data from Table 1 indicates that the Department Heads play a democratic style of leadership in formulating organizational objectives. The Department Heads aids the employees to participate and provide information in formulation of organizational objectives.

\subsubsection{Identifying Programs and Projects}

Data from Table 2 shows that the Department Heads play a democratic style of leadership in identifying programs and projects. The Department Heads seek opinions and ideas from their employees in identification process of programs and projects. The Department Heads collaborate with the employees. Collaboration among the employees may have a sufficient support on programs and projects in implementation and monitoring process.

\subsubsection{Making Decisions}

Data presented in Table 3 reflects that the Department Heads are autocratic in terms of decisions making. This indicates that the Department Heads centralized the power in their workplace. The Department Heads are the captain of the ship and held responsible in any aspects of the organization. Thus, in making decisions the Department Heads make the final choice. Nevertheless, the choice must always coincide with the competence of the decision maker. The ability to make decision alone without the skills to implement the decision is not always healthy. In fact among the chiefs of police in the province, there was an observed dichotomy between the two [13]. Hence, autocratic decision making when based on managerial competence may create an atmosphere of efficiency and effectiveness in office.

In terms of the manner they handle complaints, the participants believed that division chiefs and heads of departments follow delegative and autocratic styles of discipline as it is shown in Table 4.

\subsubsection{Handling Complaints and Issues}

Data from Table 4 indicates that the Department Heads are democratic leader in 
Table 2. Department Heads in terms of leadership in identifying programs and projects.

\begin{tabular}{|c|c|c|c|}
\hline \multicolumn{4}{|c|}{ Department Heads } \\
\hline Leadership style & 2) Identifying programs and projects & & \\
\hline DEMOCRATIC & $\begin{array}{l}\text { The inputs of programs and projects are from the ideas } \\
\text { of employees encouraged by the Department Head. }\end{array}$ & 4.30 & $\begin{array}{l}\text { Strongly } \\
\text { Agree }\end{array}$ \\
\hline AUTOCRATIC & $\begin{array}{l}\text { The inputs of programs and projects are from the ideas } \\
\text { of the Department Heads. }\end{array}$ & 3.90 & Agree \\
\hline DELEGATIVE & $\begin{array}{l}\text { Programs and projects are designed by the } \\
\text { knowledgeable employees. }\end{array}$ & 2.90 & $\begin{array}{l}\text { Moderately } \\
\text { Agree }\end{array}$ \\
\hline
\end{tabular}

Legend: 1.00 to 1.79 Strongly Disagree; 1.80 to 2.59 Disagree; 2.60 to 3.39 Moderately Agree; 3.40 to 4.19 Agree; 4.20 to 5.00 Strongly Agree.

Table 3. Department Heads in terms of decisions making.

\begin{tabular}{llll}
\hline \multicolumn{3}{c}{ Department Heads } & \\
\hline Leadership style & 3) Making decisions & & \\
\hline DEMOCRATIC & $\begin{array}{l}\text { The final decision is made by one or more employees } \\
\text { guided by the Department Head. }\end{array}$ & 3.70 & Agree \\
AUTOCRATIC & The final decision is made by the Department Head. & 4.60 & $\begin{array}{c}\text { Strongly } \\
\text { Agree }\end{array}$ \\
DELEGATIVE & The final decision is made by the competent employees. & 1.70 & $\begin{array}{c}\text { Strongly } \\
\text { Disagree }\end{array}$ \\
\hline
\end{tabular}

Legend: 1.00 to 1.79 Strongly Disagree; 1.80 to 2.59 Disagree; 2.60 to 3.39 Moderately Agree; 3.40 to 4.19 Agree; 4.20 to 5.00 Strongly Agree.

Table 4. Department Heads in terms of handling complaints and issues.

\begin{tabular}{lllll}
\hline \multicolumn{4}{c}{ Department Heads } \\
\hline Leadership style & \multicolumn{1}{c}{ 4) Handling complaints and issues } \\
\hline DEMOCRATIC & $\begin{array}{l}\text { Complaints and issues are solved by the employees and } \\
\text { Department Head. }\end{array}$ & 4.00 & Agree \\
AUTOCRATIC & $\begin{array}{l}\text { Complaints and issues are solved by the Department } \\
\text { Head. }\end{array}$ & $\begin{array}{l}\text { 3.20 } \\
\text { Complaints and issues are solved by the skilled }\end{array}$ & $\begin{array}{c}\text { Moderately } \\
\text { Agree }\end{array}$ \\
DELEGATIVE & $2.70 \begin{array}{l}\text { Moderately } \\
\text { Agree }\end{array}$ \\
\hline
\end{tabular}

Legend: 1.00 to 1.79 Strongly Disagree; 1.80 to 2.59 Disagree; 2.60 to 3.39 Moderately Agree; 3.40 to 4.19 Agree; 4.20 to 5.00 Strongly Agree.

handling complaints and issues. There is degree of collaboration and communication between the employees and Department Heads in solving the complaints and issues. These may increase the abilities of the employees through giving them responsibilities.

\subsubsection{Addressing Organizational Problems}

Data from Table 5 reflects that the Department Heads are democratic leaders in addressing organizational problems. The Department Heads decentralized the power to the member of the organization in this matter. Thus, the employees may develop a healthy sense of self-esteem. 
Table 5. Department Heads in terms of addressing organizational problems.

\begin{tabular}{lllll}
\hline \multicolumn{4}{c}{ Department Heads } & \\
\hline Leadership style & \multicolumn{1}{c}{ 5) Addressing organizational problems } & & \\
\hline DEMOCRATIC & $\begin{array}{l}\text { In solving organizational problems the Department } \\
\text { Head encourage the employees to be creative. }\end{array}$ & 4.20 & $\begin{array}{c}\text { Strongly } \\
\text { Agree }\end{array}$ \\
AUTOCRATIC & $\begin{array}{l}\text { The solutions in organizational problems are created by } \\
\text { the Department Head. }\end{array}$ & 3.60 & Agree \\
DELEGATIVE & $\begin{array}{l}\text { The Department Head allow the employees to manage } \\
\text { themselves to solve the organizational problems. }\end{array}$ & 2.60 & $\begin{array}{l}\text { Moderately } \\
\text { Agree }\end{array}$ \\
\hline
\end{tabular}

Legend: 1.00 to 1.79 Strongly Disagree; 1.80 to 2.59 Disagree; 2.60 to 3.39 Moderately Agree; 3.40 to 4.19 Agree; 4.20 to 5.00 Strongly Agree.

\subsection{Describing the Perceived Leadership Style of the LGU Division Chiefs on the Foregoing Domains}

\subsubsection{Formulating Organizational Objectives}

Data from Table 6 reflects that the Division Chiefs are democratic leader in formulating organizational objectives. The Division Chiefs encourage the employees to be actively involved in formulation of organizational objectives. Thus, may empower the employees by developing their skills and moral abilities.

\subsubsection{Identifying Programs and Projects}

Data from Table 7 indicates that the Division Chiefs are autocratic leader in identification of programs and projects. The Division Chiefs have a sole responsibility in identification process. The employees may closely monitor in implementation of programs and projects to increase productivity and efficiency.

\subsubsection{Making Decisions}

Data from Table 8 reflects that the Division Chiefs control the decisions making. The situation and problems may be clearly defined and needs immediate solution with limited time frame.

\subsubsection{Handling Complaints and Issues}

Data from Table 9 shows that the Division Chiefs is democratic leader in handling complaints and issues. The Division Chiefs distribute responsibility among the employees. Thus, the employees may develop a healthy self-esteem.

\subsubsection{Addressing Organizational Problems}

Data from Table 10 indicates that Division Chiefs are democratic in addressing organizational problems. The Department Heads aids the employees to identify the solution in solving problems. These may develop the skills of employees in speaking, thinking and organizing.

\subsection{Comparison of the Perceived Leader Style of LGU Department Heads and the Division Chiefs}

Data from Table 11 shows the computed t-statistic of -0.633 supports the hypothesis that there is no significant difference between the leadership perceptions 
Table 6. Division Chiefs in terms of formulating organizational objectives.

\begin{tabular}{|c|c|c|c|}
\hline \multicolumn{4}{|c|}{ Division Chiefs } \\
\hline Leadership style & 1) Formulating organizational objectives & & \\
\hline DEMOCRATIC & $\begin{array}{l}\text { To formulate the organizational objectives the employees } \\
\text { exercise self-direction encourage by the Division Chief. }\end{array}$ & 3.75 & Agree \\
\hline AUTOCRATIC & $\begin{array}{l}\text { To formulate the organizational objectives the Division } \\
\text { Chief direct and threatened with punishment the } \\
\text { employees. }\end{array}$ & 2.36 & Disagree \\
\hline DELEGATIVE & $\begin{array}{l}\text { The organizational objectives are formulated by the } \\
\text { employees in their own ways. }\end{array}$ & 2.68 & $\begin{array}{l}\text { Moderately } \\
\text { Agree }\end{array}$ \\
\hline
\end{tabular}

Legend: 1.00 to 1.79 Strongly Disagree; 1.80 to 2.59 Disagree; 2.60 to 3.39 Moderately Agree; 3.40 to 4.19 Agree; 4.20 to 5.00 Strongly Agree.

Table 7. Division Chiefs in identification of programs and project.

\begin{tabular}{lllll}
\hline \multicolumn{4}{c}{ Division Chiefs } & \\
\hline Leadership style & \multicolumn{1}{c}{ 2) Identifying programs and projects } & Agree \\
\hline DEMOCRATIC & $\begin{array}{l}\text { The inputs of programs and projects are from the ideas } \\
\text { of employees encouraged by the Division Chief. } \\
\text { The inputs of programs and projects are from the ideas }\end{array}$ & $\begin{array}{l}4.79 \\
\text { of the Division Chief. }\end{array}$ & Agree \\
DELEGATIVE & $\begin{array}{l}\text { Programs and projects are designed by the } \\
\text { knowledgeable employees. }\end{array}$ & 3.39 & $\begin{array}{l}\text { Moderately } \\
\text { Agree }\end{array}$ \\
\hline
\end{tabular}

Legend: 1.00 to 1.79 Strongly Disagree; 1.80 to 2.59 Disagree; 2.60 to 3.39 Moderately Agree; 3.40 to 4.19 Agree; 4.20 to 5.00 Strongly Agree.

Table 8. Division Chiefs control the decisions making.

\begin{tabular}{lllll}
\hline \multicolumn{4}{c}{ Division Chiefs } & \\
\hline Leadership style & \multicolumn{1}{c}{ 3) Making decisions } & & \\
\hline DEMOCRATIC & $\begin{array}{l}\text { The final decision is made by one or more employees } \\
\text { guided by the Division Chief. }\end{array}$ & 3.75 & Agree \\
AUTOCRATIC & The final decision is made by the Division Chief. & 4.61 & $\begin{array}{c}\text { Strongly } \\
\text { Agree }\end{array}$ \\
DELEGATIVE & The final decision is made by the competent employees. & 2.43 & Disagree \\
\hline
\end{tabular}

Legend: 1.00 to 1.79 Strongly Disagree; 1.80 to 2.59 Disagree; 2.60 to 3.39 Moderately Agree; 3.40 to 4.19 Agree; 4.20 to 5.00 Strongly Agree.

Table 9. Division Chiefs in handling complaints and issues.

\begin{tabular}{|c|c|c|c|}
\hline \multicolumn{4}{|c|}{ Division Chiefs } \\
\hline Leadership style & 4) Handling complaints and issues & & \\
\hline DEMOCRATIC & $\begin{array}{l}\text { Complaints and issues are solved by the employees and } \\
\text { Division Chief. }\end{array}$ & 4.29 & $\begin{array}{l}\text { Strongly } \\
\text { Agree }\end{array}$ \\
\hline AUTOCRATIC & Complaints and issues are solved by the Division Chief. & 3.04 & $\begin{array}{l}\text { Moderately } \\
\text { Agree }\end{array}$ \\
\hline DELEGATIVE & $\begin{array}{l}\text { Complaints and issues are solved by the skilled } \\
\text { employees. }\end{array}$ & 2.89 & $\begin{array}{l}\text { Moderately } \\
\text { Agree }\end{array}$ \\
\hline
\end{tabular}

Legend: 1.00 to 1.79 Strongly Disagree; 1.80 to 2.59 Disagree; 2.60 to 3.39 Moderately Agree; 3.40 to 4.19 Agree; 4.20 to 5.00 Strongly Agree. 
Table 10. Division Chiefs in addressing organizational problems.

\begin{tabular}{|c|c|c|c|}
\hline \multicolumn{4}{|c|}{ Division Chiefs } \\
\hline Leadership style & 5) Addressing organizational problems & & \\
\hline DEMOCRATIC & $\begin{array}{l}\text { In solving organizational problems the Division Chief } \\
\text { encourage the employees to be creative. }\end{array}$ & 4.18 & Agree \\
\hline AUTOCRATIC & $\begin{array}{l}\text { The solution in organizational problems are created by } \\
\text { the Division Chief }\end{array}$ & 3.18 & $\begin{array}{l}\text { Moderately } \\
\text { Agree }\end{array}$ \\
\hline DELEGATIVE & $\begin{array}{l}\text { The Department Head allow the employees to manage } \\
\text { themselves to solve the organizational problems. }\end{array}$ & 3.18 & $\begin{array}{l}\text { Moderately } \\
\text { Agree }\end{array}$ \\
\hline
\end{tabular}

Legend: 1.00 to 1.79 Strongly Disagree; 1.80 to 2.59 Disagree; 2.60 to 3.39 Moderately Agree; 3.40 to 4.19 Agree; 4.20 to 5.00 Strongly Agree.

Table 11. Computed t-statistic.

\begin{tabular}{|c|c|c|}
\hline Descriptive Measure & Department Heads & Division Chiefs \\
\hline Mean & 3.33 & 3.44 \\
\hline Std. Deviation & 0.588 & 0.431 \\
\hline Mean Difference & \multicolumn{2}{|c|}{-0.11086} \\
\hline $\mathrm{T}$ & \multicolumn{2}{|c|}{-0.633} \\
\hline Sig. (2-tailed)/p-value & \multicolumn{2}{|c|}{0.531} \\
\hline
\end{tabular}

No significant difference since p-value $>0.05$.

of the Department Heads to the Divisions Chiefs. Data from Table 12 indicates that the Department Heads and Division Chiefs have a complex type of leadership perception depending on the situation in organization. They have democratic leadership style in formulating organizational objectives, making decisions, in handling complaints and issues, and addressing organizational problems. But differs in identifying the programs and projects, the Department Heads are democratic while the Division Chiefs are autocratic leaders.

\section{Summary and Conclusion}

In general, no one leadership style is perceived by respondents' division chiefs and department heads of the local government of Cabanatuan City. Their management shows a blending of different styles of leadership depending on the thematic areas measured. However, dominant is the democratic style of leadership in most areas covered.

The perceived leadership styles are enumerated below.

1) The perceived leadership styles of Department Heads on

a) Formulating organizational objectives are democratic;

b) Identifying programs and projects are democratic;

c) Making decisions are autocratic;

d) Handling complaints and issues are democratic; and

e) Addressing organizational problems are democratic.

2) The perceived leadership styles of Division Chiefs on 
Table 12. Dominant Leadership Styles.

\begin{tabular}{cc}
\hline \multicolumn{2}{c}{ DOMINANT LEADERSHIP STYLES } \\
\hline DEPARTMENT HEADS & DIVISION CHIEFS \\
\hline 1) Formulating organizational objectives & 1) Formulating organizational objectives \\
DEMOCRATIC & DEMOCRATIC \\
2) Identifying programs and projects & 2) Identifying programs and projects \\
DEMOCRATIC & AUTOCRATIC \\
3) Making decisions & 3) Making decisions \\
AUTOCRATIC & AUTOCRATIC \\
4) Handling complaints and issues & 4) Handling complaints and issues \\
DEMOCRATIC & DEMOCRATIC \\
5) Addressing organizational problems & 5) Addressing organizational problems \\
DEMOCRATIC & DEMOCRATIC \\
\hline
\end{tabular}

a) Formulating organizational objectives are democratic;

b) Identifying programs and projects are autocratic;

c) Making decisions are autocratic;

d) Handling complaints and issues are democratic; and

e) Addressing organizational problems are democratic.

3) There is no significant difference between the perceived leadership styles of Department Heads and Division Chiefs.

The study of leadership styles is as old as human aggregation. From the city state of "polis" to public governance era, the role of leadership is indispensable in steering up the wheel of the organization to a greater vision and higher level of performance. The study suggests that in terms of leadership style and its effectiveness, contingency is more likely to suit to the changing Philippine politico-administrative set up of local government units.

\section{References}

[1] Gabriel, A.G. and Gutierrez, M.P. (2017) Praxis in Local Legislative Governance: Measure of Organizational Effectiveness of the Component Cities in Nueva Ecija, Philippines. Asia Pacific Journal of Multidisciplinary Research, 5, No. 2.

[2] Gabriel, A.G. (2017) Transparency and Accountability in Local Government: Levels of Commitment of Municipal Councilors in Bongabon in the Philippines. Asia Pacific Journal of Public Administration, 39, 217-223. https://doi.org/10.1080/23276665.2017.1368902

[3] Drucker, P. (n.d.) Management: Task, Responsibilities, Practices. https://www.goodreads.com/quotes/656219-leadership-is-not-magnetic-personality -that-can-just-as-well

[4] Pareek and Rao (with Jyote J. and Bhau S.) (2015) Impact of Transformational Leadership on Job Performance: Mediating Role of Leader-Member Exchange and Relational Identification. 1-13.

[5] Nanjundeswaraswamy, T.S. and Swamy, D.R. (2014) Leadership Styles. JSS Acade- 
my of Technical Education, Bangalore.

[6] Betts, H. (2018) Effective Leadership-It's All about the Style.

https://www.linkedin.com/pulse/effective-leadership-its-all-style-howard-betts

[7] Boateng, I. (2014) A Quantitative Case Study of Transformational Leadership Characteristics of Valley View University in Ghana. Andrews University, West Africa.

[8] Cherry, K. (2017) What Is Transformational Leadership? A Closer Look at the Effects of Transformational Leadership.

https://www.verywellmind.com/what-is-transformational-leadership-2795313

[9] Gastil, J. (1994) A Definition and Illustration of Democratic Leadership. Article in Human Relations. https://doi.org/10.1177/001872679404700805

[10] Hollander, E.P. (2012) Leader-Follower Relations and the Dynamics of Inclusion and Idiosyncrasy Credit. 201-221.

[11] Hollander, E. (2012) Developing Leaders for Tomorrow: Power and Leadership in Organizations Relationships in Transition.

https://www.scribd.com/document/78058258/Power-and-Leadership-in-Organizati ons

[12] Siegel, D. (2015) Leaders in the Shadows: The Leadership Qualities of Municipal Chief Administrative Officers. University of Toronto Press, Canada.

[13] Eduardo, J.P. and Gabriel, A.G. (2017) Assessing the Leadership Skills of the Chiefs of Police in the Towns of Nueva Ecija, Philippines. A Dichotomy Between Managerial Competence and Decision Making Ability. Open Journal of Leadership, 6, 142-159. https://doi.org/10.4236/ojl.2017.64011 